\title{
Somatic Cell Count During and Between Milkings
}

\author{
R. G. M. Olde Riekerink, ${ }^{\star 1}$ H. W. Barkema,† W. Veenstra,‡ F. E. Berg,‡ H. Stryhn, ${ }^{*}$ and R. N. Zadoks§ \\ *Department of Health Management, University of Prince Edward Island, Charlottetown, C1A 4P3 Canada \\ †Faculty of Veterinary Medicine, University of Calgary, Calgary, T2N 4N1 Canada \\ $\ddagger$ Faculty of Veterinary Medicine, Utrecht University, Utrecht, the Netherlands \\ §Quality Milk Production Services, Cornell University, Ithaca, NY 14850
}

\begin{abstract}
The objectives of the study were to determine 1) how sampling time between milkings affects the sensitivity and specificity of somatic cell count (SCC) as an indicator for intramammary infection (IMI) status, and 2) which cells are responsible for the diurnal variation in SCC. Six Prince Edward Island, Canada, dairy herds were selected. Quarter samples for SCC were collected immediately before the a.m. milking (pre-a.m.), halfway through the a.m. milking, immediately after the a.m. milking, every 60 min after detachment of the milking unit, and immediately before the p.m. milking (prep.m.). Compared with the geometric mean SCC at the pre-a.m. milking, SCC of quarters with no IMI between milkings was higher up to $7 \mathrm{~h}$ after milking. The prep.m. SCC was significantly lower than the pre-a.m. SCC in quarters with no IMI. Specificity of SCC at a cutoff of 200,000 or 500,000 cells $/ \mathrm{mL}$ as an indicator for IMI status declined substantially after the a.m. milking. In quarters with elevated SCC, the proportion of polymorphonuclear leukocytes was larger immediately after milking. For accurate interpretations of SCC testswhether by a laboratory, portable SCC device, or the California Mastitis Test-veterinarians, researchers, and udder health advisors should take milk samples immediately before milking.
\end{abstract}

Key words: somatic cell count, diurnal variation, dairy, milk

\section{INTRODUCTION}

Somatic cell count is the most frequently used indicator of subclinical mastitis in dairy cattle. The most important cause of increased SCC is a bacterial infection of the mammary gland (Dohoo and Meek, 1982; Harmon, 1994). Nonbacterial factors that affect SCC include age, stage of lactation, season, stress, management, day-to-

Received January 2, 2007.

Accepted April 10, 2007.

${ }^{1}$ Corresponding author: rolderiek@upei.ca day variation, and diurnal variation. These factors are considered less important than IMI status (Dohoo and Meek, 1982; Reneau, 1986; Harmon, 1994). However, diurnal variation of SCC could have consequences for the interpretation of SCC data if milk samples are collected at any time other than immediately before or during milking (Dohoo and Meek, 1982). Milk samples for SCC analysis as part of DHI programs are routinely collected at milking time. For researchers and veterinarians, sample collection during milking may not always be feasible. Furthermore, with increased use of portable somatic cell counters, milk samples are more likely to be taken between milkings by dairy producers or their advisors. The sensitivity and specificity of SCC at a threshold of 200,000 cells $/ \mathrm{mL}$ as an indicator of the presence of IMI are estimated at 73 and $86 \%$, respectively (Dohoo and Leslie, 1991). If the SCC changes after milking, a correction factor may be needed to obtain the same sensitivity and specificity for SCC as an indicator of IMI.

Diurnal variation has been suggested to be the result of proportional dilution relative to milking interval, and is thought to be larger in high-producing cows than in low-producing cows (Reneau, 1986). The most recent study on diurnal variation that included between-milking variation dates from 1967 (White and Rattray, 1965; Cullen, 1967; Smith and Schultze, 1967), and milk production has more than doubled since then. With decreasing mean individual cow SCC and increased milk production per cow, it may be possible that the SCC decreases faster postmilking nowadays, and samples that are indicative of IMI status can be taken sooner after milking.

Each somatic cell type has its own specified function in the immune response of the mammary gland: a high SCC can be the result of an increase in PMNL (Leitner et al., 2000). No studies have reported the fluctuation of these cells during the day synchronic with the diurnal variation of the SCC. The objectives of the study were to determine: 1) how sampling time affects the sensitivity and specificity of SCC as an indicator of IMI status, and 2) which cells are responsible for the diurnal variation in SCC. 
Table 1. Overview of 60 cows that were selected on previous DHI SCC, stage of lactation (DIM), parity, and daily milk production (as recorded the previous day)

\begin{tabular}{|c|c|c|c|c|c|c|c|}
\hline \multirow[b]{2}{*}{ Stage of lactation ${ }^{1}$} & \multicolumn{3}{|c|}{ Parity } & \multicolumn{3}{|c|}{ Daily milk production, $\mathrm{kg}$} & \multirow[b]{2}{*}{ Tota } \\
\hline & 1 & 2 & $>2$ & $10-20$ & $20-30$ & 30 & \\
\hline \multicolumn{8}{|l|}{ Low-SCC group } \\
\hline 10-100 DIM & 1 & 3 & 1 & 0 & 2 & 3 & 5 \\
\hline 101-200 DIM & 4 & 2 & 5 & 1 & 6 & 4 & 11 \\
\hline 201-300 DIM & 4 & 2 & 3 & 4 & 5 & 0 & 9 \\
\hline$>300$ DIM & 1 & 3 & 1 & 2 & 3 & 0 & 5 \\
\hline \multicolumn{8}{|l|}{ High-SCC group } \\
\hline 10-100 DIM & 0 & 2 & 4 & 0 & 1 & 5 & 6 \\
\hline 101-200 DIM & 1 & 1 & 2 & 2 & 1 & 1 & 4 \\
\hline 201-300 DIM & 3 & 3 & 8 & 12 & 1 & 1 & 14 \\
\hline$>300$ DIM & 1 & 3 & 2 & 3 & 3 & 0 & 6 \\
\hline Total & 15 & 19 & 26 & 24 & 22 & 14 & 60 \\
\hline
\end{tabular}

${ }^{1}$ Low-SCC group $=$ SCC $<200,000$ cells $/ \mathrm{mL} ;$ high-SCC group $=$ SCC $\geq 200,000$ cells $/ \mathrm{mL}$.

\section{MATERIALS AND METHODS}

\section{Herd and Cow Selection}

Six Prince Edward Island, Canada, dairy farms that housed lactating cows in tie-stalls and milked cows twice daily were selected. Each herd was milked in the a.m. and p.m. with a 9- to 10-h interval, as measured from the end of the a.m. milking to the start of the p.m. milking. Within each herd, 9 to 11 cows were selected that had 4 milk-producing udder quarters, no clinical mastitis, and a production of more than $10 \mathrm{~kg} / \mathrm{d}$. In addition, an effort was made to obtain a similar distribution in the following categories: last DHI test $\leq 200,000$ or $>200,000$ cells $/ \mathrm{mL}$; first, second, or third and later lactation; early ( $\leq 100 \mathrm{DIM}), \operatorname{mid}(101$ to 200 DIM), or late ( $>200$ DIM) lactation; and $<20,20$ to 30 , or $>30 \mathrm{~kg} / \mathrm{d}$ of milk production (Table 1 ).

\section{Milk Samples}

Immediately before the a.m. milking (pre-a.m.) and immediately before the p.m. milking (pre-p.m.), quarter milk samples were collected in a $60-\mathrm{mL}$ plastic vial after wiping off the udder with a clean, dry paper towel and removing 3 squirts of milk. The milk sample just before the a.m. milking was taken in duplicate. Quarter samples halfway through the a.m. milking, immediately after the a.m. milking, and every $60 \mathrm{~min}$ after detachment of the milking unit were collected in 60$\mathrm{mL}$ plastic vials after removing 3 squirts of milk. The midpoint of the a.m. milking was estimated based on milk production of the cow (in $\mathrm{kg}$ ) at the previous a.m. milking. Sterile quarter milk samples for bacteriological analysis were collected in duplicate at the pre-a.m. and pre-p.m. points after SCC samples were taken and the teat was disinfected with a squeezed alcoholdrenched cotton.
Samples for differential cell counting were collected from 20 cows on 2 farms ( 10 on each farm). At each sampling moment, $5 \mathrm{~mL}$ of milk was collected and poured into a sterile glass vial immediately after collection. Samples were subsequently stored in a cooler box on ice packs and transported to the laboratory, where they were stored overnight at $4^{\circ} \mathrm{C}$.

\section{Laboratory Analyses}

Somatic cell count was determined within $24 \mathrm{~h}$ after collection of milk samples using an electronic cell counter (Fossomatic Series 400, Foss Electric A/S, Hillerød, Denmark). In total, 21 (0.7\%) observations of 13 quarters in 6 cows were excluded from the SCC analysis because there was an insufficient amount of milk in the sample.

Preparation of differential cell count samples and microscopic differential cell count were performed based on the techniques described by Schröder and Hamann (2005). In detail, the milk in glass tubes was centrifuged 2 times for $10 \mathrm{~min}$ at 1,516 $\times \mathrm{g}$. A fat layer was removed after the first centrifugation, and after the second centrifugation the remaining fat and supernatant were removed until $0.25 \mathrm{~mL}$ of fluid was left. The remaining cell pellet was resuspended in the remaining $0.25 \mathrm{~mL}$. From this suspension, $25 \mu \mathrm{L}$ was spread over a microscope slide. The slide was dried on a slide warmer, fixed with methanol, and stained with Wright's stain using an automated stainer (HEMA-TEK 2000, model 4488B, Bayer Diagnostics, Tarrytown, NY). On each slide, up to 100 cells were identified, at a magnification of $1,000 \times$.

\section{Bacteriological Analysis}

Bacteriological culture was performed according to National Mastitis Council standards (Hogan et al., 
1999). For each sample, the number of colony-forming units of each bacterial species was counted. Of the pathogens that were cultured, Staphylococcus aureus, Streptococcus agalactiae, Streptococcus dysgalactiae, Streptococcus uberis, other Streptococcus spp., and Escherichia coli were considered major pathogens, whereas coagulase-negative staphylococci, Corynebacterium bovis, enterococci, and Bacillus spp. were considered minor pathogens (Barkema et al., 1999). A quarter was considered infected with a major pathogen if the same organism was cultured from both pre-a.m. samples. A quarter was considered to be infected with a minor pathogen if the same pathogen was cultured from both pre-a.m. samples and at least one milk sample produced $\geq 1,000 \mathrm{cfu} / \mathrm{mL}$. If no diagnosis could be made based on the pre-a.m. cultures, the pre-p.m. samples were cultured and the same rules as for the pre-a.m. cultures were applied. If 3 or more bacterial species were cultured from a sample, the sample was considered contaminated.

Quarters were divided into 3 categories based on infection status: no IMI, IMI with minor pathogens, and IMI with major pathogens. If a quarter was infected with both a minor and a major pathogen, it was considered to be infected with a major pathogen.

\section{Statistical Analysis}

Data were checked for unlikely values. Separate analyses were carried out for SCC during milking (prea.m. sampling, halfway through the a.m. milking, immediately after the a.m. milking, and pre-p.m. sampling) and between milking (h 1 to 9 after the pre-a.m. sampling), as well as for the proportions of PMNL and of macrophages and monocytes during and between milkings.

The SCC analyses used linear mixed models with herd fixed effects, cow random effects, and a direct product correlation structure on quarters and time to account for correlations between and within quarters over time (Galecki, 1994). To approximate the normal distribution, a natural logarithmic transformation of SCC values (1,000 cells/mL) was used (Ali and Shook, 1980). The main advantage of a direct product correlation structure, compared with a standard hierarchical model with a repeated-measures correlation structure within quarters (Dohoo et al., 2003), is that it extends the within-quarter correlation structure to betweenquarter correlations. Specifically, the between-milking analysis used a first-order autoregressive correlation structure for the time component, whereby correlations both within and between quarters decayed over time. A variable for parity was removed from the model because it was not significant $(P>0.05)$. Milk production was dichotomized into low and high milk-producing cows at $22 \mathrm{~kg} / \mathrm{d}$, the median of the cows involved in this study. Lactation stage was divided into 3 categories: early (DIM $\leq 100)$, mid $(100<$ DIM $\leq 200)$, and late (DIM $>200$ ). The resulting model for the difference between the natural logarithm of pre-a.m. Somatic cell counts and the natural logarithm of SCC at a time in the between-milking interval, the $l$ th measurement in quarter $k$ in cow $j$ in herd $i$ was as follows:

$$
\begin{gathered}
\operatorname{lndiffSCC}_{\mathrm{ijkl}}=\beta_{0}+\beta_{1} \text { hour }_{1}+\beta_{2} \text { minor }_{\mathrm{ijk}} \\
+\beta_{3} \text { major }_{\mathrm{ijk}}+\beta_{4} \text { himilk }_{\mathrm{ij}}+\beta_{5} \operatorname{dim}_{\mathrm{ij}}+\beta_{6} \mathrm{f}_{\mathrm{ijk}} \\
+\beta_{7} \mathrm{lr}_{\mathrm{ijk}}+\beta_{8} \mathrm{rf}_{\mathrm{ijk}}+\beta_{9}\left(\text { hour }_{1} \times \text { minor }_{\mathrm{ijk}}\right) \\
+\beta_{10}\left(\text { hour }_{1} \times \text { major }_{\mathrm{ijk}}\right)+\beta_{11}\left(\text { hour }_{1} \times \text { himilk }_{\mathrm{ij}}\right) \\
+\gamma_{\mathrm{i}}+u_{\mathrm{ij}}+\varepsilon_{\mathrm{ijk}},
\end{gathered}
$$

where $\beta_{0}$ is the intercept; $\beta_{1}$ is the regression coefficient for time after milking in hours; $\beta_{2}$ and $\beta_{3}$ are regression coefficients for infection with a minor $\left(\beta_{2}\right)$ or major pathogen $\left(\beta_{3}\right) ; \beta_{4}$ and $\beta_{5}$ are the regression coefficients for high milk production $\left(\beta_{4}\right)$ and DIM $\left(\beta_{5}\right) ; \beta_{6}$ to $\beta_{8}$ are the regression coefficients for quarters; $\beta_{9}$ to $\beta_{11}$ are the regression coefficients of the interactions between hours after milking and IMI status $\left(\beta_{9}\right.$ and $\left.\beta_{10}\right)$ and between hours after milking and production level $\left(\beta_{11}\right)$; $\gamma_{\mathrm{i}}$ is the regression coefficient for herd $i$; $u_{\mathrm{ij}}$ is the cow random effect; and $\varepsilon_{\mathrm{ijkl}}$ is the error term with a direct product autoregressive correlation structure on quarters and time.

For during-milking SCC, a similar linear mixed model with a direct product correlation structure was used, except that the within-quarter correlations were modeled as unstructured instead of autoregressive because of the irregular spacing in time. Pairwise comparisons of sample times within IMI levels as well as of IMI levels within sample times were adjusted for multiple comparisons by the Bonferroni method. Nonsignificant effects of quarter, herd, lactation stage, and high milk production $(P>0.05)$ were omitted. The model for the natural logarithm of SCC at certain moments during milking, the $l$ th measurement in quarter $k$ in cow $j$ in herd $i$, was as follows:

$$
\begin{aligned}
& \operatorname{lnSCC} \mathrm{ijkl}_{\mathrm{j} l}=\beta_{0}+\beta_{1} \text { minor }_{\mathrm{ijk}}+\beta_{2} \text { major }_{\mathrm{ijk}} \\
& +\beta_{3} \text { halfway }_{1}+\beta_{4} \text { post-a.m.l }+\beta_{5} \text { pre-p.m.l } \\
& +\beta_{6}\left(\text { minor }_{\mathrm{ijk}} \times \text { halfway }_{\mathrm{l}}\right) \\
& +\beta_{7}\left(\text { minor }_{\mathrm{ijk}} \text { post-a.m.l }_{.1}\right)+\beta_{8}\left(\text { minor }_{\mathrm{ijk}} \text { pre-p.m.l }\right) \\
& +\beta_{9}\left(\text { major }_{\mathrm{ijk}} \times \text { halfwayl }_{1}\right)+\beta_{10}\left(\text { major }_{\mathrm{ijk}} \times \text { post-a.m.l }\right) \\
& +\beta_{11}\left(\text { major }_{\mathrm{ijk}} \times \text { pre-p.m.l }\right)+u_{\mathrm{ij}}+\varepsilon_{\mathrm{ijkl}} \text {, }
\end{aligned}
$$

where $\beta_{0}$ is the intercept; $\beta_{1}$ and $\beta_{2}$ are regression coefficients for IMI status; $\beta_{3}$ to $\beta_{5}$ are the regression coeffi- 
cients of sample moment; $\beta_{6}$ to $\beta_{11}$ are the regression coefficients of the interaction of IMI status and sample moment; $u_{\mathrm{ij}}$ is the cow random effect; and $\varepsilon_{\mathrm{ijkl}}$ is the error term with a direct product unstructured correlation structure on quarters and time. With IMI status as the gold standard, sensitivity and specificity were calculated for each sampling moment for 2 cutoff values of SCC: 200,000 and 500,000 cells $/ \mathrm{mL}$.

Because of low observed proportions of lymphocytes, squamous cells, and degenerated cells, only the proportions of PMNL as well as of macrophages and monocytes (combined) were subjected to statistical analysis. All analyses were based on logistic regression models with random effects for cows and quarters as well as a firstorder autoregressive repeated-measures correlation structure within quarters and an extrabinomial dispersion parameter. Nonsignificant effects of quarter and herd $(P>0.05)$ were omitted. The models for the proportions of PMNL or of macrophages and monocytes between milkings were as follows:

$$
\begin{aligned}
& \operatorname{logit}\left(p_{\mathrm{ijkl}}\right)=\beta_{0}+\beta_{1} \operatorname{hiscc}_{\mathrm{ij}}+\beta_{2} \operatorname{hour}_{1} \\
& +\beta_{3}\left(\operatorname{hour}_{1} \times \operatorname{hiscc}_{\mathrm{ij}}\right)+u_{\mathrm{ij}}+v_{\mathrm{ijk}},
\end{aligned}
$$

and the models for the proportions of PMNL or of macrophages and monocytes among the cells identified at certain moments during milking were as follows:

$$
\begin{gathered}
\operatorname{logit}\left(p_{\mathrm{ijkl}}\right)=\beta_{0}+\beta_{1} \operatorname{hiscc}_{\mathrm{ij}}+\beta_{2} \text { halfway }_{\mathrm{l}} \\
+\beta_{3} \text { post-a.m.l }+\beta_{4} \text { pre-p.m.l } \\
+\beta_{5}\left(\text { halfwayl } \times \text { hiscc }_{\mathrm{ij}}\right)+\beta_{6}\left(\text { post-a.m.l }_{\cdot \mathrm{l}} \text { hiscc }_{\mathrm{ij}}\right) \\
+\beta_{7}\left(\text { pre-p.m.l }_{\cdot \mathrm{l}} \times \operatorname{hiscc}_{\mathrm{ij}}\right)+u_{\mathrm{ij}}+v_{\mathrm{ijk}}
\end{gathered}
$$

where $\operatorname{logit}(p)=\ln [p /(1-p)] ; p_{\mathrm{ijkl}}$ is the proportion of a cell type in a sample taken at sampling moment $l$ from quarter $k$ within cow $j$ within herd $i ; \beta_{0}$ is the intercept; $\beta_{1}$ is the regression coefficient for quarters with high SCC ( $>200,000$ cells $/ \mathrm{mL}) ; \beta_{2}$ and $\beta_{3}$ in model [3] are the regression coefficients for time after milking in hours $\left(\beta_{2}\right)$ and its interaction with high SCC; $\beta_{2}$ to $\beta_{7}$ in model [4] are the regression coefficients for sample moments $\left(\beta_{2}\right.$ to $\beta_{4}$ ) and their interaction with high SCC; $u_{\mathrm{ij}}$ is the cow random effect; and $v_{\mathrm{ijk}}$ is the quarter random effect.

All mixed-model analyses were carried out using SAS software (SAS for Windows, version 9.1, SAS Institute, Inc., Cary, NC): the linear mixed models by PROC MIXED, and the generalized linear mixed models by the experimental PROC GLIMMIX. All other statistical calculations were carried out with Stata software (Intercooled Stata for Windows, version 8.2, Stata Corporation, College Station, TX).

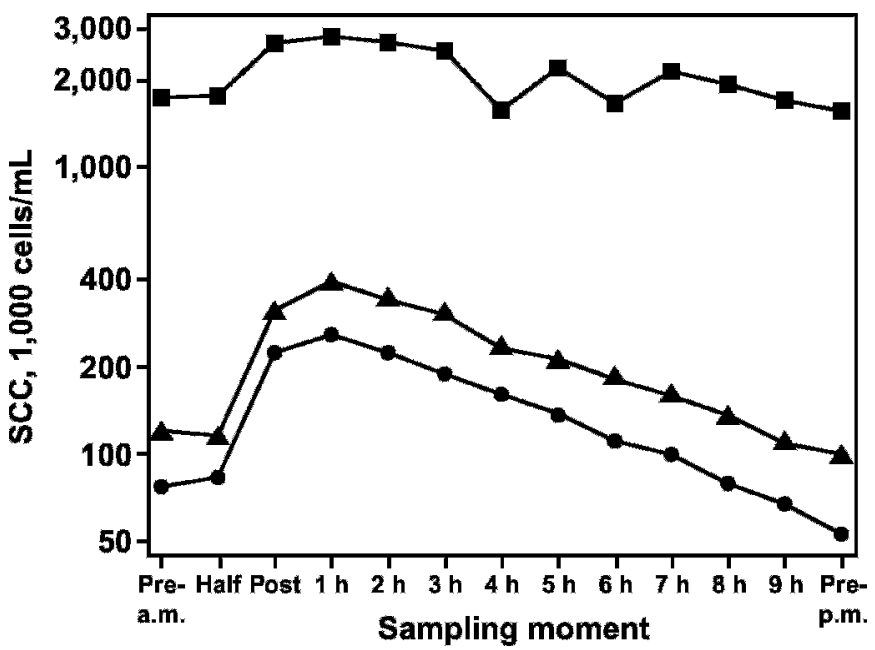

Figure 1. Geometric mean quarter $(\mathrm{n}=240)$ SCC during and between milkings for quarters without an IMI $(\bullet ; n=192)$, quarters with an infection with minor pathogens $(\mathbf{\Delta} ; \mathrm{n}=31)$, and quarters with an infection with major pathogens $(\mathbf{\square} ; \mathrm{n}=17)$.

\section{RESULTS}

\section{Culture Results}

In total, $17(7.1 \%)$ quarters were infected with major pathogens: 11 Staph. aureus, 1 mixed infection with Staph. aureus and Strep. dysgalactiae, 1 Strep. uberis, 3 Streptococcus spp. other than Strep. agalactiae, Strep. uberis, or Strep. dysgalactiae, and $1 E$. coli. Thirty-one (12\%) quarters were infected with minor pathogens: 12 coagulase-negative staphylococci and 19 C. bovis. Two samples were considered contaminated.

\section{SCC}

The geometric mean SCC of all quarters $(\mathrm{n}=240)$ included in the study was 101,000 cells $/ \mathrm{mL}$ (ranging from 5,000 to $7,677,000$ cell s/mL) at the pre-a.m. sampling and increased sharply after the a.m. milking (Figure 1) to a maximum of 322,000 cells $/ \mathrm{mL} 1 \mathrm{~h}$ after milking (ranging from 15,000 to $8,136,000$ cells $/ \mathrm{mL}$ ). Compared with the geometric mean SCC at the prea.m. sampling, SCC of postmilking samples were higher until $7 \mathrm{~h}$ after milking (Figure 1). For example, substituting the estimated coefficients of Table 2 in model [1], the natural logarithm of the right front quarter with no IMI in a high-producing, midlactation cow in herd 2 would be elevated at $3 \mathrm{~h}$ after milking (compared with the pre-a.m. sampling) by an amount of $1.179+$ $(-0.144 \times 3)+0+(0.604 \times 1)+0.479+(-0.162)+0+$ $(3 \times-0.052)+(-0.205)=1.47$ (Table 2$)$.

The mean SCC of quarters with a major pathogen IMI was higher than for quarters with a minor pathogen 
Table 2. Mixed model of the difference between the natural logarithm of the pre-a.m. SCC and the natural logarithm of the between-milking SCC of 240 quarters of 60 cows

\begin{tabular}{lccc}
\hline Item & Coefficient $\beta^{1}$ & $\mathrm{SE}$ & $P$-value \\
\hline Intercept & 1.179 & 0.174 & $<0.01$ \\
Quarter & & & $<0.01$ \\
Left front & Ref. & - & \\
Right front & -0.162 & 0.074 & \\
Left rear & -0.243 & 0.049 & \\
Right rear & -0.315 & 0.066 & \\
Hour & -0.144 & 0.013 & $<0.01$ \\
IMI & & & $<0.01$ \\
None & Ref. & - & \\
Minor pathogen & -0.077 & 0.123 & \\
Major pathogen & 0.764 & 0.175 & \\
Milk ${ }^{3}>22$ kg/d & 0.604 & 0.168 & $<0.01$ \\
Stage of lactation & & & $<0.01$ \\
Early, <101 DIM & Ref. & - & \\
Mid, 101-200 DIM & 0.479 & 0.135 & \\
Late, $>200$ DIM & 0.407 & 0.141 & \\
Hour $\times$ IMI & & & $<0.01$ \\
None & Ref. & - & \\
Minor pathogen & 0.012 & 0.019 & \\
Major pathogen & 0.083 & 0.026 & \\
Hour $\times$ milk $>22$ kg/d & -0.052 & 0.018 & $<0.01$ \\
Herd & & & 0.05 \\
Herd 1 & Ref. & - & \\
Herd 2 & -0.205 & 0.162 & \\
Herd 3 & -0.131 & 0.177 & \\
Herd 4 & -0.260 & 0.143 & \\
Herd 5 & -0.482 & 0.160 & \\
Herd 6 & -0.284 & 0.149 & \\
\hline 1 & & &
\end{tabular}

${ }^{1}$ Ref. $=$ reference category.

${ }^{2}$ Hour after the end of milking as a continuous variable.

${ }^{3}$ Milk production per day, dichotomized at the median.

IMI or no IMI and did not increase much after the a.m. milking (Figure 1 and Table 2). Somatic cell counts of quarters with a minor pathogen IMI differed little from quarters with no IMI (Figure 1 and Table 2). Compared with low-producing cows, the difference between prea.m. SCC and SCC in high-producing cows $1 \mathrm{~h}$ after the a.m. milking was bigger and declined faster after that time (Table 2). The difference between SCC at the pre-a.m. sampling and SCC between milkings was smaller in quarters of cows in early lactation than in cows later in lactation (Table 2). Compared with rear quarters, front quarters had larger differences in SCC between the pre-a.m. sampling and between milkings; in addition, left front quarters had larger differences than right front quarters, and left rear quarters had larger differences than right rear quarters (Table 2).

For quarters with no IMI, the pre-a.m. SCC increased from a least squares estimate of 75,000 cells $/ \mathrm{mL}$ to an estimated postmilking SCC level of 220,000 cells $/ \mathrm{mL}$ $(P<0.01$; Table 3$)$. The SCC levels at the halfway milking were not significantly different from the pre-a.m. level (Table 3). At the pre-p.m. sampling, the SCC was
Table 3. Mixed model of the natural logarithm of pre-a.m. SCC, and the natural logarithm of the between-milking SCC of 240 quarters of 60 cows

\begin{tabular}{lccc}
\hline Item ${ }^{1}$ & Coefficient $\beta^{2}$ & $\mathrm{SE}$ & $P$-value \\
\hline Intercept & 4.322 & 0.144 & \\
IMI & & & $<0.01$ \\
$\quad$ None & Ref. & - & \\
Minor pathogen & 0.660 & 0.232 & \\
Major pathogen & 2.915 & 0.304 & \\
Sampling moment & & & $<0.01$ \\
Pre-a.m. & Ref. & - & \\
Halfway & 0.107 & 0.061 & \\
Post-a.m. & 1.071 & 0.072 & \\
Pre-p.m. & -0.349 & 0.080 & \\
IMI $\times$ sampling moment & & & $<0.01$ \\
Minor pathogen $\times$ pre-a.m. & Ref. & - & \\
Minor pathogen $\times$ halfway & -0.130 & 0.109 & \\
Minor pathogen $\times$ post-a.m. & -0.104 & 0.130 & \\
Minor pathogen $\times$ pre-p.m. & 0.066 & 0.144 & \\
Major pathogen $\times$ pre-a.m. & Ref. & - & \\
Major pathogen $\times$ halfway & 0.054 & 0.142 & \\
Major pathogen $\times$ post-a.m. & -0.344 & 0.170 & \\
Major pathogen $\times$ pre-p.m. & 0.431 & 0.188 & \\
\hline
\end{tabular}

${ }^{1}$ Pre-a.m. $=$ sampling moment is immediately before the a.m. milking; pre-p.m. = sampling moment is immediately before the p.m. milking.

${ }^{2}$ Ref. $=$ reference category.

53,000 cells $/ \mathrm{mL}$ for quarters with no IMI, lower than the pre-a.m. SCC $(P<0.01$; Table 3$)$. For quarters with a major pathogen IMI, the pre-p.m. (1,509,000 cells/mL) and halfway milking SCC $(1,634,000$ cells $/ \mathrm{mL})$ were not significantly different from the pre-a.m. SCC $(1,390,000$ cells $/ \mathrm{mL})$, whereas the postmilking SCC $(2,877,000$ cells $/ \mathrm{mL}$ ) was different.

The sensitivity of SCC as an indicator of major pathogen IMI at a cutoff of 200,000 cells $/ \mathrm{mL}$ was $100 \%$ at almost any moment of sampling (Figure 2). The specificity of SCC as an indicator of major pathogen IMI dropped from $73 \%$ [95\% exact binomial confidence interval (CI): 67 to $79 \%$ ] premilking to $34 \%$ (95\% CI: 28 to 41\%) $1 \mathrm{~h}$ after milking and then increased slowly until the p.m. milking (Figure 2). When both major and minor pathogen IMI were considered, the specificity of SCC followed a similar pattern, but the sensitivity was much lower. The specificity was 37\% (95\% CI: 30 to 44\%) 1 $\mathrm{h}$ after milking, whereas the sensitivity started at $52 \%$ (95\% CI: 37 to $67 \%$ ) at the pre-a.m. sampling, increased to $89 \%$ (95\% CI: 76 to $96 \%$ ) $1 \mathrm{~h}$ after milking, and slowly declined back to $52 \%$ (95\% CI: 37 to $67 \%$ ) at the p.m. sampling (Figure 2).

The sensitivity to determine an IMI with a major pathogen using a cutoff value of 500,000 cells $/ \mathrm{mL}$ was $82 \%$ and higher at any moment of the sampling period (Figure 3). The specificity at a cutoff value of 500,000 cells $/ \mathrm{mL}$ at the pre-a.m. sampling was initially $91 \%$ (95\% CI: 86 to 94\%) and dropped to 70\% (95\% CI: 63 


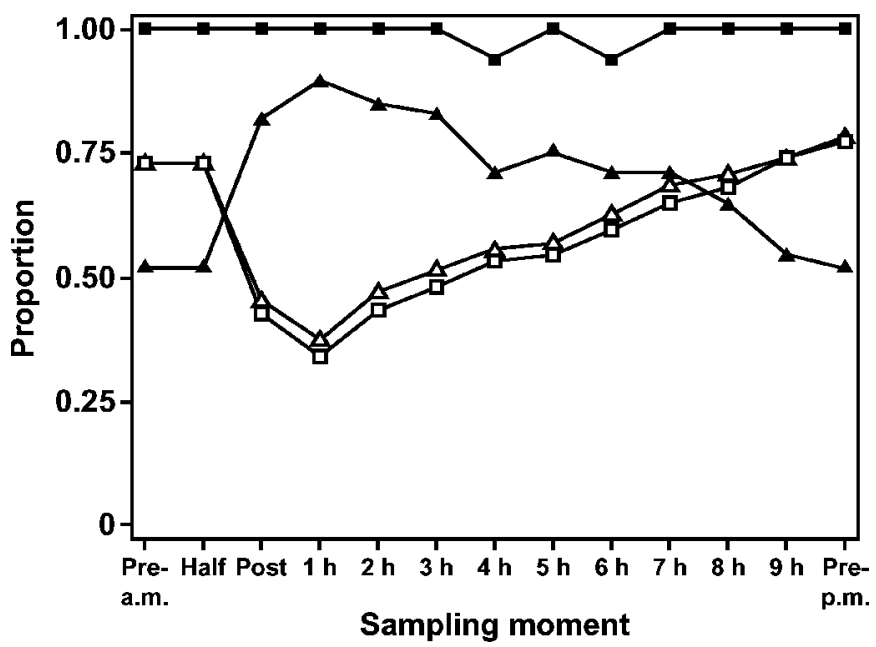

Figure 2. Sensitivity ( $\square$ ) and specificity $(\square)$ of SCC at the threshold of 200,000 cells $/ \mathrm{mL}$ to determine an IMI with major pathogens or for any IMI (sensitivity $=\mathbf{\Delta}$; specificity $=\Delta$ ) during and between milkings.

to $76 \%$ ) at $1 \mathrm{~h}$ after milking (Figure 3 ). The specificity of SCC to determine any IMI at the cutoff value of 500,000 cells $/ \mathrm{mL}$ followed a pattern similar to that of the major pathogens, whereas the sensitivity was $40 \%$ (95\% CI: 26 to 55\%) at the pre-a.m. sampling, reached its highest value at $65 \%$ (95\% CI: 50 to $79 \%$ ) $1 \mathrm{~h}$ after milking, and decreased slowly to premilking levels up to the p.m. milking (Figure 3).

\section{Cell Differentiation}

The mean number of cells counted per slide was 81 . In $70.1 \%$ of slides $(n=1,036)$ more than 90 cells were

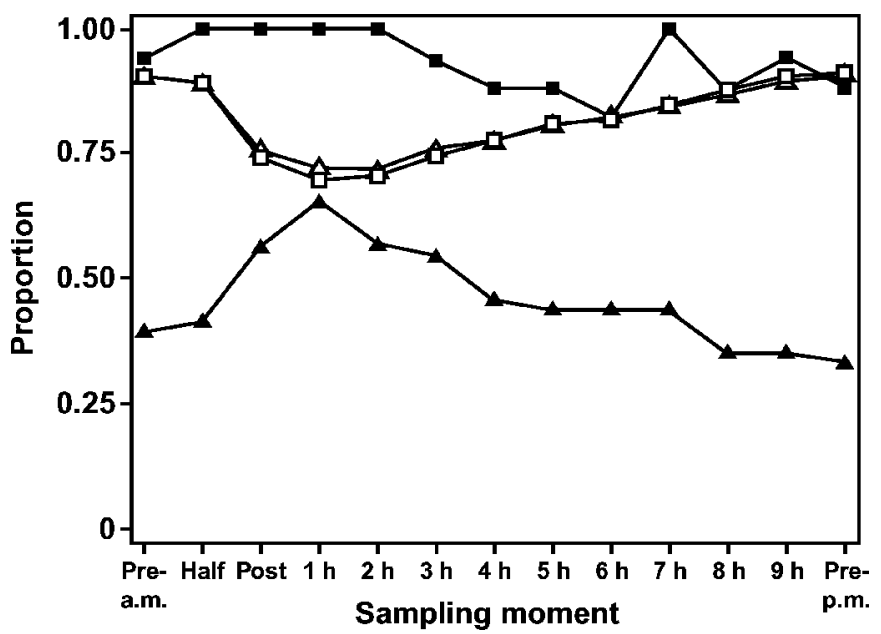

Figure 3. Sensitivity ( $\square$ ) and specificity $(\square)$ of SCC at the threshold of 500,000 cells $/ \mathrm{mL}$ to determine an IMI with major pathogens or for any IMI (sensitivity $=\boldsymbol{\Delta}$; specificity $=\Delta$ ) during and between milkings. counted, and in $3.7 \%$ less than 10 . The proportions of macrophages and monocytes, PMNL, lymphocytes, squamous cells, and degenerated cells in milk samples with a low SCC $(\leq 200,000$ cells $/ \mathrm{mL})$ and taken after removal of the foremilk were $66,22,0.3,7.5$, and $4.2 \%$, respectively, compared with $54,38,1.1,3.4$, and $2.6 \%$ in milk samples with elevated SCC $(>200,000$ cells $/ \mathrm{mL}$; Figure 4). In low-SCC quarters, the proportions of PMNL did not change, whereas in high-SCC quarters, the proportions of PMNL were larger than in low-SCC quarters at any time, but decreased toward the p.m. milking (Figure 4 and Table 4). The proportions of macrophages and monocytes decreased slightly between milkings in low-SCC quarters and were larger at any time than in high-SCC quarters; in high-SCC quarters, these proportions increased over time between milkings (Figure 4 and Table 4). The proportions of PMNL were largest in high-SCC quarters (except at the pre-p.m. sampling), but were only significantly elevated relative to the pre-a.m. sampling immediately after the a.m. milking (Figure 4 and Table 4). In low-SCC quarters, the proportions of macrophages and monocytes were significantly larger in the halfway and post-a.m. milk samples compared with the pre-a.m. sample, and at most sampling moments, they were smaller in highSCC quarters (Figure 4 and Table 4).

\section{DISCUSSION}

Somatic cell counts in quarter milk samples changed considerably during the day. The observed diurnal variation of SCC was in agreement with earlier research (White and Rattray, 1965; Cullen, 1967; Smith and Schultze, 1967; White and Rattray, 1967). There are several possible scenarios in which the diurnal variation of SCC could be explained: 1) decreasing cell influx and constant milk influx; 2) constant cell influx and increasing milk influx; and 3) the combination of decreasing cell influx and increasing milk influx between milkings. Several studies have demonstrated that milk flow in the udder cistern increases from $4 \mathrm{~h}$ after milking onward (Knight et al., 1994; Bruckmaier, 2005). Other studies have shown that the proportion of PMNL in the blood supply to the udder changes in the time after milking (Paape and Guidry, 1969; Knight et al., 1994). Although not proven, but based on the increased proportion of PMNL reported in the blood supply of the udder (Paape and Guidry, 1969), we hypothesized that changes in SCC between milkings were possibly caused by a relatively high influx of cells shortly after milking and a subsequent dilution effect due to the increased milk influx hours later.

Handling of the cow and quarters 3 times during milking and every hour thereafter until the p.m. milk- 


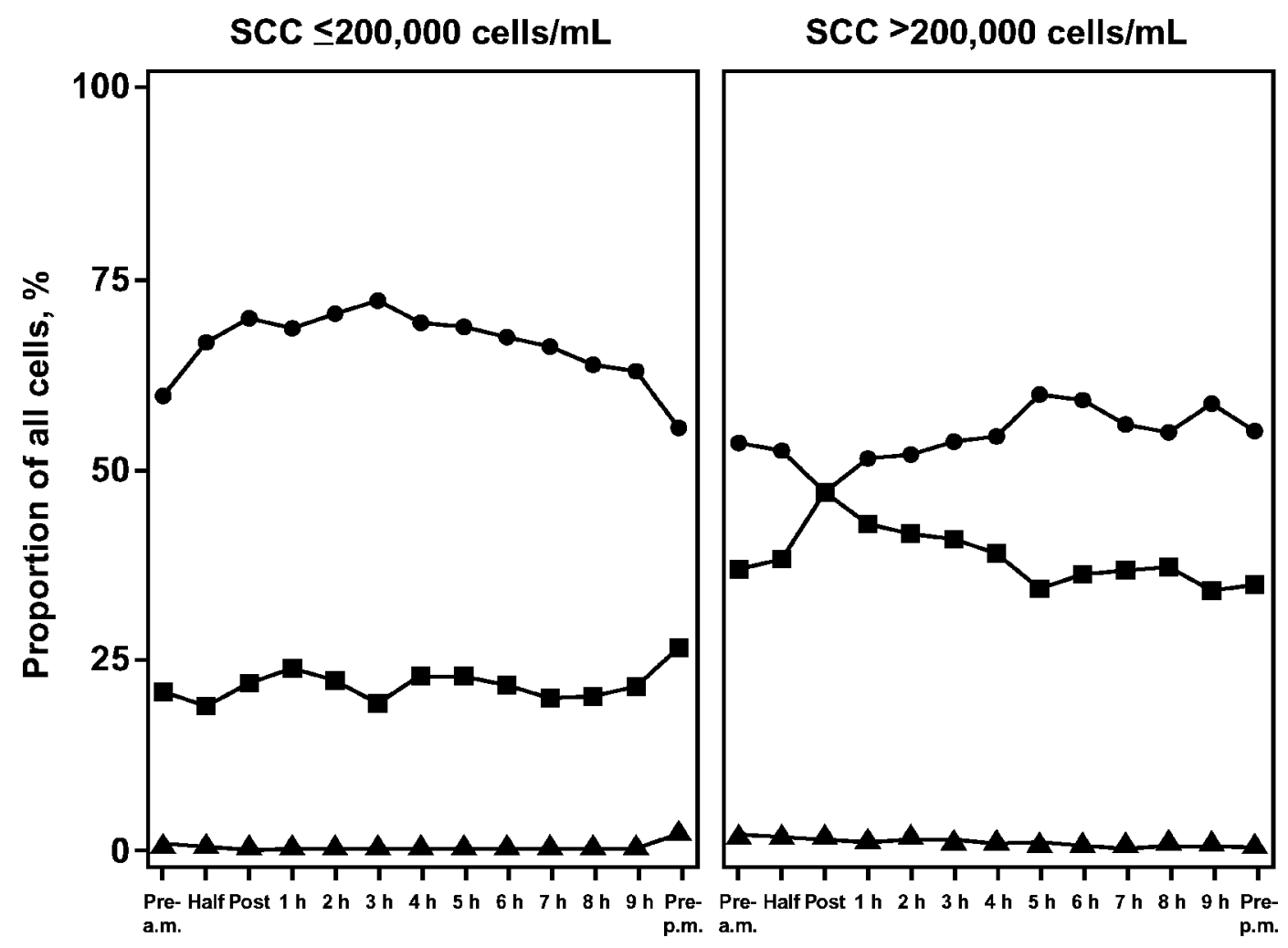

Sampling moment

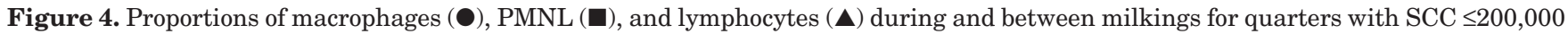
cells $/ \mathrm{mL}(\mathrm{n}=56)$ and SCC $>200,000$ cells $/ \mathrm{mL}(\mathrm{n}=24)$. Proportions of squamous cells and degenerated cells were omitted from the figure.

Table 4. Logistic regression models of proportions of PMNL and macrophages and monocytes between and during milkings in 80 quarters of 20 cows in 2 herds

\begin{tabular}{|c|c|c|c|c|c|c|}
\hline \multirow[b]{2}{*}{ Variable $^{1}$} & \multicolumn{3}{|c|}{ PMNL } & \multicolumn{3}{|c|}{ Macrophages and monocytes } \\
\hline & $\beta$ & $\mathrm{SE}$ & $P$ & $\beta$ & $\mathrm{SE}$ & $P$ \\
\hline \multicolumn{7}{|l|}{ Between milking } \\
\hline Intercept & -1.288 & 0.217 & & 0.898 & 0.167 & \\
\hline High SCC & 0.756 & 0.204 & $<0.01$ & -0.772 & 0.158 & $<0.01$ \\
\hline Hour & -0.004 & 0.013 & 0.75 & -0.026 & 0.012 & 0.21 \\
\hline High SCC $\times$ hour & -0.051 & 0.020 & 0.01 & 0.077 & 0.019 & $<0.01$ \\
\hline \multicolumn{7}{|l|}{ During milking } \\
\hline Intercept & -1.446 & 0.307 & & 0.440 & 0.167 & \\
\hline High SCC & 0.548 & 0.140 & $<0.01$ & -0.071 & 0.154 & 0.65 \\
\hline Sample moment & & & $<0.01$ & & & 0.07 \\
\hline Pre-a.m. & Ref. & - & & Ref. & - & \\
\hline Halfway & -0.061 & 0.099 & & 0.391 & 0.115 & \\
\hline Post-a.m. & 0.228 & 0.099 & & 0.391 & 0.111 & \\
\hline Pre-p.m. & 0.296 & 0.114 & & -0.123 & 0.125 & \\
\hline High $\mathrm{SCC} \times$ sample moment & & & $<0.01$ & & & $<0.01$ \\
\hline Pre-a.m. & Ref. & - & & Ref. & - & \\
\hline Halfway & 0.251 & 0.191 & & -0.425 & 0.186 & \\
\hline Post-a.m. & 0.290 & 0.194 & & -0.708 & 0.183 & \\
\hline Pre-p.m. & -0.488 & 0.224 & & 0.076 & 0.208 & \\
\hline
\end{tabular}

${ }^{1}$ High SCC $=$ SCC $>200,000$ cells $/ \mathrm{mL}$; hour = time after detachment of the unit at the a.m. milking; prea.m. = sample taken immediately before the a.m. milking; halfway = sample taken halfway through the a.m. milking; post-a.m. = sample taken immediately after detachment of the unit at the a.m. milking; prep.m. = sample taken immediately before the p.m. milking. 
ing could have affected SCC somewhat because mechanical stimulation of the udder seems to be associated with increased SCC (Rasmussen et al., 2005). Because the proportion of squamous cells in milk was small and constant in our study, we believed that mechanical stimulation had only a minimal effect and would not have influenced the outcome of our study. Milk leakage between sampling was occasionally seen, but the authors did not consider this as a major influence on SCC, nor on the outcomes of the study.

Significant differences in SCC, associated with quarter position, were observed between quarters within a cow, similar to other studies. The incidence of clinical mastitis is higher in rear quarters than in front quarters (Batra et al., 1977; Adkinson et al., 1993; Barkema et al., 1997). Right quarters are associated with a higher incidence of clinical mastitis (Barkema et al., 1997) and subclinical mastitis (Zadoks et al., 2001) than are left quarters. A recent study by Berry and Meaney (2006) found that subclinical mastitis, defined as SCC $>250,000$ cells $/ \mathrm{mL}$, occurred more often than expected in rear quarters than in front quarters.

The diurnal variation in SCC has consequences for the use of SCC as an indicator of IMI status. The sensitivity and specificity of SCC was explored for 2 thresholds: 200,000 and 500,000 cells $/ \mathrm{mL}$. Based on sensitivity and specificity, a cutoff value of 200,000 cells $/ \mathrm{mL}$ is considered the most appropriate threshold for diagnosis of IMI with major pathogens (Dohoo and Leslie, 1991; Schukken et al., 2003). A cutoff level of 500,000 cells/ $\mathrm{mL}$ was also considered because it reflects the recommended threshold for diagnosis of IMI with the California Mastitis Test (Casura et al., 1995). For both thresholds, the sensitivity of finding an IMI with major pathogens remains high. Shortly after the a.m. milking, SCC is relatively high, resulting in a high proportion of falsepositive diagnoses of IMI and low test specificity. Our results suggest that a correction formula may be developed for SCC values between milkings based on a broader study population than the present one.

No difference was found between SCC pre-a.m. and halfway through the a.m. milking. A higher SCC in strict foremilk (defined as the first 2 stripped jets of milk) than cisternal or alveolar milk fractions taken from quarters with SCC $>100,000$ cells $/ \mathrm{mL}$ has been reported (Sarikaya and Bruckmaier, 2006). We collected samples only after the foremilk (in our case, the first 3 strippings of milk) was removed. By contrast, postmilking SCC was much higher than pre-a.m. SCC. This difference may be a result of the start of an influx of white blood cells before the end of milking. Another explanation is that the cow was milked out completely and the sample, which was taken after the removal of the unit, contained the first milk with many cells produced after milking. The SCC was considerably lower at the pre-p.m. sampling than at the pre-a.m. sampling. Earlier studies have reported higher mean SCC pre-p.m. than pre-a.m. (White and Rattray, 1965; Cullen, 1967; Smith and Schultze, 1967; White and Rattray, 1967; Reneau, 1986; Nielsen et al., 2005). This discrepancy could be the result of the herds in the present study having 9 to $10 \mathrm{~h}$ between the a.m. and p.m. milkings, whereas some studies had only $7 \mathrm{~h}$ between the start of the a.m. and p.m. milkings (Cullen, 1967; Smith and Schultze, 1967; Reneau, 1986). Nielsen et al. (2005) reported higher SCC during most of the milking process at 6 -h milking intervals, compared with 12 -h milking intervals. At 6 to $7 \mathrm{~h}$ after the a.m. milking in our study, SCC was still higher than the pre-a.m. level. By contrast, Weiss et al. (2002) used proportional sampling and found no difference when cows were milked at various intervals.

The proportions of macrophages, PMNL, lymphocytes, squamous cells, and degenerated cells were similar to those reported earlier for quarters of normal, healthy cows (Kurzhals et al., 1985). The proportion of PMNL in quarters with an elevated SCC was almost twice the proportion of PMNL in milk from quarters with a low SCC. The larger proportion of PMNL can be explained by the chemotactical mobilization of PMNL induced by macrophages in the udder in response to an IMI. In quarters with elevated SCC, the relative proportion of PMNL was larger shortly after milking than later on (Figure 4).

The finding that the pre-p.m. SCC was significantly lower than the pre-a.m. SCC has implications for the interpretation of DHI data and sampling. In some countries, for example, in Canada, DHI organizations sometimes alternate herd sampling between the a.m. and p.m. milkings. This means that between measures, cows have, on average, higher or lower SCC, depending on the time of sampling. Our results also imply that samples collected from all cows in herds that are not enrolled in a DHI program at moments other than premilking do not reflect the average herd SCC and that the average would not be a good predictor of the bulk milk SCC.

\section{CONCLUSIONS}

In quarter samples collected between milkings, SCC is not a reliable indicator of the IMI status. Differential cell ratios did not change much during the day in quarters with low SCC; therefore, the SCC fluctuation between milkings in these quarters was attributed to no specific cell type. Quarters with an elevated SCC, however, showed a relatively higher proportion of PMNL shortly after milking, followed by a gradual decline to 
premilking levels. The proportion of macrophages mirrored this pattern. To make optimal interpretations of SCC tests-whether by a laboratory, a portable SCC device, or the California Mastitis Test-veterinarians, researchers, and udder health advisors should take the milk samples immediately before milking.

\section{ACKNOWLEDGMENTS}

The authors wish to thank the cooperating dairy farmers for making their herds available, and Wendy Smith, Doris Poole, Philippe Puylaert, Thomas Ogilvie, and Barb Horney for their assistance.

\section{REFERENCES}

Adkinson, R. W., K. H. Ingawa, D. C. Blouin, and S. C. Nickerson. 1993. Distribution of clinical mastitis among quarters of the bovine udder. J. Dairy Sci. 76:3453-3459.

Ali, A. K. A., and G. E. Shook. 1980. An optimum transformation for somatic cell concentration in milk. J. Dairy Sci. 63:487-490.

Barkema, H. W., Y. H. Schukken, T. J. Lam, M. L. Beiboer, G. Benedictus, and A. Brand. 1999. Management practices associated with the incidence rate of clinical mastitis. J. Dairy Sci. $82: 1643-1654$

Barkema, H. W., Y. H. Schukken, T. J. Lam, D. T. Galligan, M. L. Beiboer, and A. Brand. 1997. Estimation of interdependence among quarters of the bovine udder with subclinical mastitis and implications for analysis. J. Dairy Sci. 80:1592-1599.

Batra, T. R., B. J. Nonnechke, F. H. Newbould, and R. R. Hacker. 1977. Incidence of clinical mastitis in a herd of Holstein cattle. J. Dairy Sci. 60:1169-1172.

Berry, D. P., and W. J. Meaney. 2006. Interdependence and distribution of subclinical mastitis and intramammary infection among udder quarters in dairy cattle. Prev. Vet. Med. 75:81-91.

Bruckmaier, R. M. 2005. Normal and disturbed milk ejection in dairy cows. Domest. Anim. Endocrinol. 29:268-273.

Casura, C., Y. H. Schukken, and P. Rüsch. 1995. Quality assessment of California Mastitis Test as a diagnostic tool in quarter somatic cell count estimation. Pages 57-58 in Proc. 3rd Int. IDF Mastitis Seminar, Tel Aviv, Israel. Int. Dairy Fed., Brussels, Belgium.

Cullen, G. A. 1967. Short term variations in the cell count of cows' milk. Vet. Rec. 80:649-653.

Dohoo, I. R., and K. E. Leslie. 1991. Evaluation of changes in somatic cell counts as indicators of new intramammary infections. Prev. Vet. Med. 10:225-237.

Dohoo, I. R., S. W. Martin, and H. Stryhn. 2003. Veterinary Epidemiologic Research. AVC-Inc., Charlottetown, Prince Edward Island, Canada.

Dohoo, I. R., and A. H. Meek. 1982. Somatic cell counts in bovine milk. Can. Vet. J. 23:119-125.
Galecki, A. T. 1994. General class of covariance structure for two or more repeated factors in longitudinal data analysis. Commun. Stat. Theory Methods 23:3105-3120.

Harmon, R. J. 1994. Physiology of mastitis and factors affecting somatic cell counts. J. Dairy Sci. 77:2103-2112.

Hogan, J. S., R. N. González, R. J. Harmon, S. C. Nickerson, S. P. Oliver, J. W. Pankey, and K. L. Smith. 1999. Laboratory Handbook on Bovine Mastitis. Rev. ed. National Mastitis Council, Verona, WI.

Knight, C. H., D. Hirst, and R. J. Dewhurst. 1994. Milk accumulation and distribution in the bovine udder during the interval between milkings. J. Dairy Res. 61:167-177.

Kurzhals, P., H. Klima, and D. Manz. 1985. Beziehungen zwischen Zellzahl, Zellbild und bakteriologischen Befunden bei der subklinischen Mastitis des Rindes. Milchwissenschaft 40:6-9.

Leitner, G., E. Shoshani, O. Krifucks, M. Chaffer, and A. Saran. 2000. Milk leucocyte population patterns in bovine udder infection of different aetiology. J. Vet. Med. B Infect. Dis. Vet. Public Health $47: 581-589$.

Nielsen, N. I., T. Larsen, M. Bjerring, and K. L. Ingvartsen. 2005. Quarter health, milking interval, and sampling time during milking affect the concentration of milk constituents. J. Dairy Sci. 88:3186-3200

Paape, M. J., and A. J. Guidry. 1969. Effect of milking on leucocytes in the subcutaneous abdominal vein of the cow. J. Dairy Sci. 52:998-1002.

Rasmussen, M. D., M. Bjerring, and F. Skjoth. 2005. Visual appearance and CMT score of foremilk of individual quarters in relation to cell count of cows milked automatically. J. Dairy Res. 72:49-56.

Reneau, J. K. 1986. Effective use of dairy herd improvement somatic cell counts in mastitis control. J. Dairy Sci. 69:1708-1720.

Sarikaya, H., and R. M. Bruckmaier. 2006. Importance of the sampled milk fraction for the prediction of total quarter somatic cell count. J. Dairy Sci. 89:4246-4250.

Schröder, A. C., and J. Hamann. 2005. The influence of technical factors on differential cell count in milk. J. Dairy Res. 72:153-158.

Schukken, Y. H., D. J. Wilson, F. Welcome, L. Garrison-Tikofsky, and R. N. González. 2003. Monitoring udder health and milk quality using somatic cell counts. Vet. Res. 34:579-596.

Smith, J. W., and W. D. Schultze. 1967. Variation in cell content of milk associated with time of sample collection. I. Diurnal variation. J. Dairy Sci. 50:1083-1087.

Weiss, D., M. Hilger, H. H. D. Meyer, and R. M. Bruckmaier. 2002. Variable milking intervals and milk composition. Milchwissenschaft 57:246-249.

White, F., and E. A. Rattray. 1965. Diurnal variation in the cell content of cows' milk. J. Comp. Pathol. 75:253-261.

White, F., and E. A. Rattray. 1967. The role of white cells and frequency of milking in the control of staphylococcal mastitis. J. Comp. Pathol. 77:143-151.

Zadoks, R. N., H. G. Allore, H. W. Barkema, O. C. Sampimon, G. J. Wellenberg, Y. T. Gröhn, and Y. H. Schukken. 2001. Cow- and quarter-level risk factors for Streptococcus uberis and Staphylococcus aureus mastitis. J. Dairy Sci. 84:2649-2663. 